\title{
INHIBITION OF OESTROUS BEHAVIOUR IN EWES BY PASSIVE IMMUNIZATION AGAINST OESTRADIOL-17 $\beta$
}

\author{
R. J. SCARAMUZZI \\ M.R.C. Unit of Reproductive Biology, Department of Obstetrics and Gynaecology, \\ University of Edinburgh, 39 Chalmers Street, Edinburgh EH3 9ER
}

(Received 14th Fune 1974)

The biological activity of a steroid can be readily neutralized by high-affinity antibodies directed against the steroid, thus providing a useful method of studying its effects. Biological neutralization with antibodies to low molecular weight hormones can be produced either by active immunization against an hormonal hapten (Scaramuzzi, Caldwell, Tillson \& Thorneycroft, 1970), or by the passive transfer of antibodies to the hormone (Vande Wiele, Ferin, Raziano, Dyrenfurth \& Mikhail, 1970). The widespread use of these methods has not been possible in the past because of difficulties in generating antisera to steroid haptens and the relatively small quantities of antisera produced. The availability of reliable quick methods for the production of antisera to hormones of low molecular weight (Vaitukaitis, Robbins, Nieschlag \& Ross, 1971) has been reflected by the increased application of these methods to biological studies (Cowchok \& co-authors, 1973; Hillier, Cole, Groom, Boyns \& Cameron, 1973; Nieschlag, Usadel, Schwedes, Kley, Schöffling \& Krüskemper, 1973; Sundaram, Tsong, Hood \& Brinson, 1973; Thorneycroft, 1973).

Active immunization results in long-term neutralization of hormonal activity. Neutralization by the passive transfer of antisera would be preferable when, as during the oestrous cycle, the hormonal environment is changing rapidly. In the present report, antisera specific to oestradiol-17 $\beta$ have been used to neutralize the ability of oestradiol benzoate (ODB: $25 \mu \mathrm{g}$ ) to induce oestrus in the ovariectomized ewe primed with progesterone.

Antiserum to oestradiol-17 $\beta$ was produced in large quantities by immunizing six wethers against a conjugate of oestradiol-6-bovine serum albumen (BSA) as described by Scaramuzzi, Corker, Young \& Baird (1974). Fifty-four separate antisera (nine from each of the six animals) were pooled to give approximately 6 litres of anti-oestradiol serum which was then characterized (Scaramuzzi et al., 1974) and used in the tests described.

Sixteen ewes, ovariectomized at least 2 months earlier, were used in a series of five tests conducted at monthly intervals during the 1973/74 breeding season. Before each test, all ewes were primed with intramuscular injections of $10 \mathrm{mg}$ progesterone daily for 12 days (Robinson, 1959) and, $48 \mathrm{hr}$ after the last injection, $25 \mu \mathrm{g}$ ODB were administered to induce oestrous behaviour. The antioestradiol serum or non-immune control serum was given by subcutaneous injection $3 \mathrm{hr}$ before ODB. In some tests, the antiserum was administered simultaneously with the ODB. For the following $72 \mathrm{hr}$, the ewes were placed in 

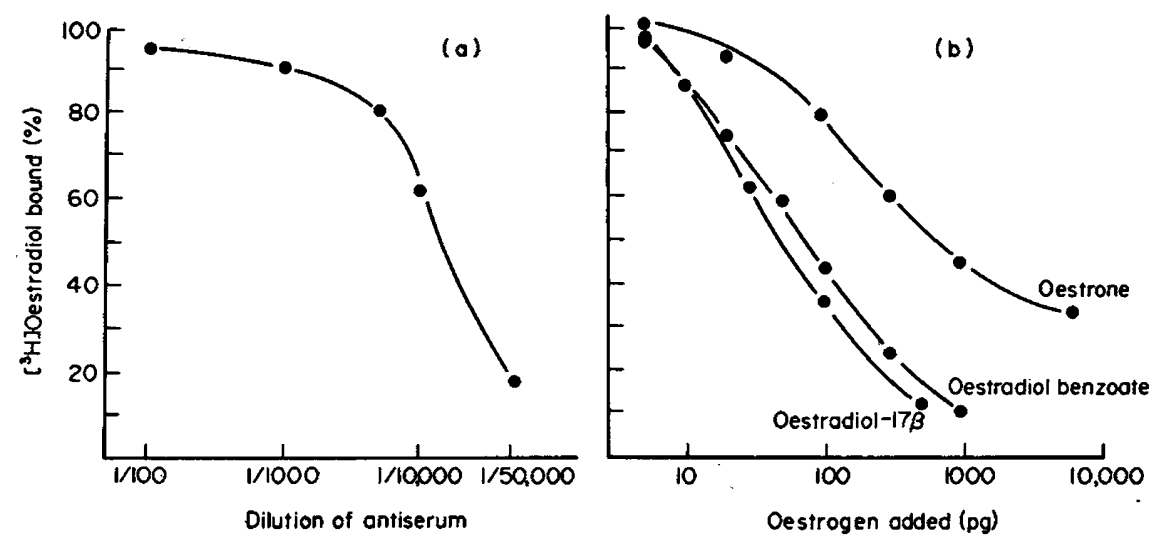

TEXT-FIG. 1. Characteristics of pooled antiserum to oestradiol-6-bovine serum albumen. (a) The titre of the pooled antiserum; (b) inhibition curves for oestradiol-17 $\beta$, oestradiol benzoate and oestrone.

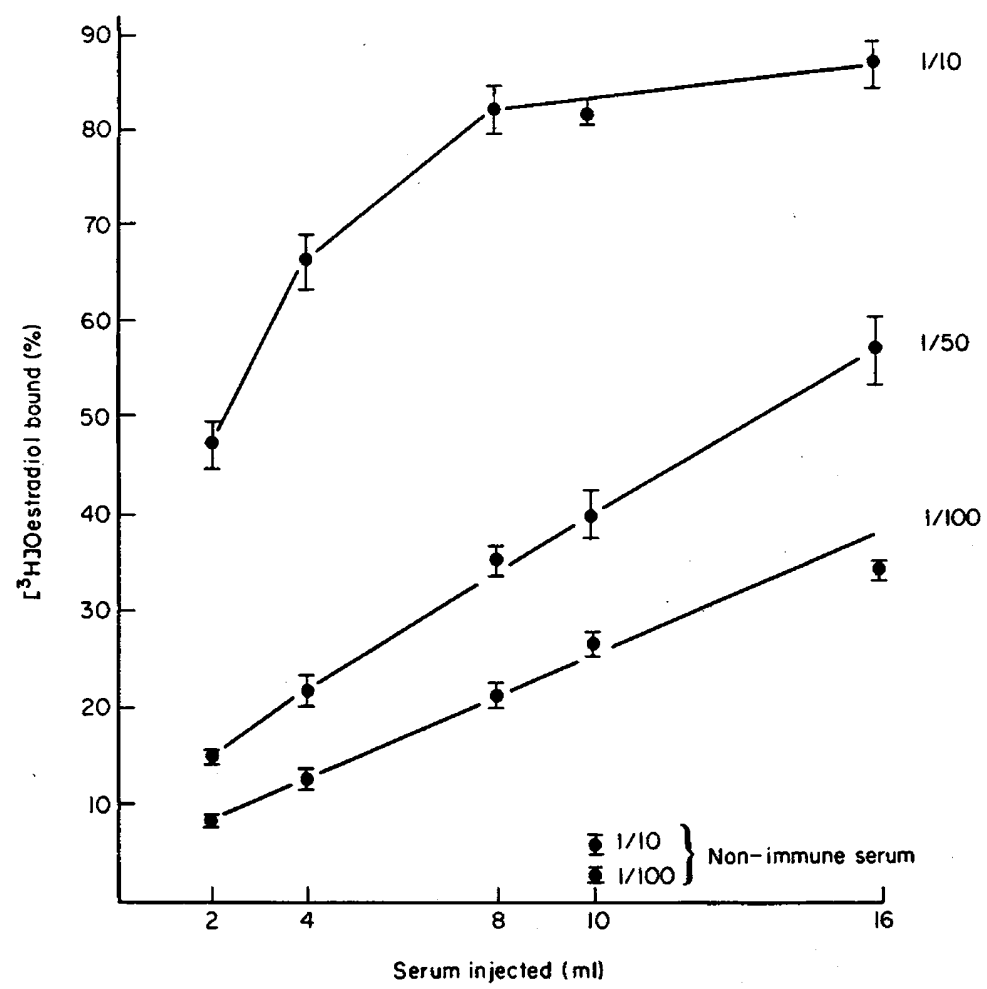

TEXT-FIG. 2. The percentage binding of $\left[6,7-{ }^{3} \mathrm{H}\right]$ oestradiol-17 $\beta$ to three dilutions of plasma from ewes passively immunized with different volumes of antiserum to oestradiol-6bovine serum albumen (two to six ewes) or to two dilutions of plasma from ewes previously injected with $10 \mathrm{ml}$ non-immune serum (four ewes). The points and vertical bars represent the Means \pm S.E.M. 
a field with a raddled ram and were examined twice daily for evidence of oestrous behaviour. Antiserum titres were measured in samples of jugular venous plasma taken immediately before, and at 1,2 and 3 days after passive immunization. The procedures used to determine the titre and the specificity of the pooled antiserum have been described in detail by Scaramuzzi et al. (1974). The specificity and titre of the pooled antiserum used to produce passive immunization of the ewes are illustrated in Text-fig. 1. The titre of an antiserum is defined as that dilution which binds $50 \%$ of the added tracer (Thorneycroft, Tillson, Abraham, Scaramuzzi \& Caldwell, 1970) and was $1 / 14,000$ for the pooled antiserum. Cross-reactions (relative to oestradiol-17 $\beta$ ) for oestrone, oestradiol benzoate and oestradiol-17 $\alpha$ (not illustrated) were $7.5 \%, 77.8 \%$ and $3.0 \%$ respectively at $50 \%$ displacement (Text-fig. 1 ). The titres of antiserum in ewes passively immunized with pooled antiserum are shown in Text-fig. 2 . The binding at two dilutions of plasma from ewes immunized with non-immune serum was negligible $(5 \cdot 4 \pm 1 \cdot 1 \%$ at $1 / 10$, and $2 \cdot 2 \pm 0 \cdot 2 \%$ at $1 / 100)$. The quantity of $\left[6,7-{ }^{3} \mathrm{H}\right]$ oestradiol- $17 \beta$ which was bound showed a linear increase with the increasing amounts of anti-oestradiol serum injected (Text-fig. 2).

The antiserum titre remained unchanged for up to $72 \mathrm{hr}$ after passive immunization (Table 1) and, in some cases, low but detectable antiserum titres were present 28 days after passive immunization.

Table 1. Percentage binding of $\left[6,7-{ }^{3} \mathrm{H}\right]$ oestradiol- $17 \beta$ to dilutions of plasma at various intervals after subcutaneous injection of $10 \mathrm{ml}$ antiserum to oestradiol-6-BSA or $10 \mathrm{ml}$ non-immune serum

\begin{tabular}{|c|c|c|c|c|c|c|c|}
\hline \multirow[t]{2}{*}{ Serum treatment } & \multirow{2}{*}{$\begin{array}{l}\text { No. } \\
\text { of } \\
\text { ewes }\end{array}$} & \multirow{2}{*}{$\begin{array}{c}\text { Time } \\
\text { after } \\
\text { injection } \\
\text { (days) }\end{array}$} & \multicolumn{5}{|c|}{ Dilution of plasma } \\
\hline & & & $1 / 10$ & $1 / 50$ & $1 / 100$ & $1 / 500$ & $1 / 1000$ \\
\hline $\begin{array}{l}\text { Non-immune serum } \\
\text { Antiserum } \\
\text { Antiserum } \\
\text { Antiserum } \\
\text { Antiserum }\end{array}$ & $\begin{array}{l}4 \\
6 \\
6 \\
6 \\
4\end{array}$ & $\begin{array}{r}1 \\
1 \\
2 \\
3 \\
28\end{array}$ & $\begin{array}{r}5 \cdot 4 \pm 1 \cdot 0 \\
74 \cdot 5 \pm 2 \cdot 6 \\
81 \cdot 0 \pm 1 \cdot 6 \\
73 \cdot 7 \pm 2 \cdot 7 \\
46 \cdot 0 \pm 2 \cdot 9\end{array}$ & $\begin{array}{r}2 \cdot 8 \pm 0 \cdot 2 \\
37 \cdot 2 \pm 4 \cdot 5 \\
39 \cdot 6 \pm 2 \cdot 5 \\
44 \cdot 3 \pm 3 \cdot 5 \\
12 \cdot 0 \pm 1 \cdot 1\end{array}$ & $\begin{array}{r}2 \cdot 2 \pm 0.2 \\
22 \cdot 2 \pm 2 \cdot 9 \\
26 \cdot 7 \pm 1 \cdot 1 \\
23 \cdot 8 \pm 2 \cdot 1 \\
7 \cdot 0 \pm 0.9\end{array}$ & $\begin{array}{l}2 \cdot 2 \pm 0 \cdot 1 \\
6 \cdot 3 \pm 0.7 \\
6 \cdot 6 \pm 0.2 \\
6 \cdot 5 \pm 0.5 \\
2 \cdot 0 \pm 0.0\end{array}$ & $\begin{array}{l}1 \cdot 7 \pm 0 \cdot 1 \\
4 \cdot 3 \pm 0 \cdot 4 \\
4 \cdot 4 \pm 0 \cdot 2 \\
4 \cdot 3 \pm 0 \cdot 4 \\
1 \cdot 5 \pm 0 \cdot 2\end{array}$ \\
\hline
\end{tabular}

Values are expressed as means \pm S.E.M.

The proportions of ewes showing oestrous behaviour in each control group was almost $100 \%$ and the small difference was not significant (11/11 untreated controls versus $7 / 8$ controls treated with $10 \mathrm{ml}$ non-immune serum). Treatment with $10 \mathrm{ml}$ anti-oestradiol serum $3 \mathrm{hr}$ before ODB depressed the oestrous response $(1 / 13$ versus $7 / 8)$. When $10 \mathrm{ml}$ antiserum were injected simultaneously with ODB, the blocking of oestrous behaviour was less effective and a smaller difference was observed ( $3 / 6$ versus $7 / 8)$. Likewise $5 \mathrm{ml}$ antisera injected before ODB did not inhibit oestrous behaviour very effectively (4/8 versus $7 / 8$ ).

The present data show that large volumes of specific antisera with high titres against oestradiol-6-BSA can be readily produced by immunizing sheep. There can be little doubt that similar results could be obtained with other proteinsteroid conjugates (Scaramuzzi et al., 1974). The specificity of the pooled antisera against oestradiol-6-BSA has been determined in vitro at a dilution of 
$1 / 20,000$ and these data show that the antiserum has a high degree of specificity for oestradiol- $17 \beta$. The specificity of the antiserum in vivo and at much higher concentrations of antibodies was not determined.

The ovariectomized ewe primed with progesterone is a well-established model for assessing the effect of oestrogen and $25 \mu \mathrm{g}$ ODB will reliably induce oestrus in $90 \%$ or more of such sheep (Robinson, 1959). In the present experiments, 18/19 of the progesterone-primed ewes given ODB without antiserum showed oestrous behaviour. The ability of antisera to oestradiol-6-BSA to achieve partial neutralization of the oestrus-inducing activity of $25 \mu \mathrm{g}$ ODB given at the same time (Table 1) shows that the antiserum is quickly absorbed following subcutaneous injection. No change was seen in the oestradiol-binding capacity of plasma taken from ewes up to $72 \mathrm{hr}$ after passive immunization, indicating that antibodies against oestradiol persist in the circulation for at least 3 days (Table 1).

The technical help of Mr W. G. Davidson and Mrs G. Heavon-Jones is gratefully acknowledged.

\section{REFERENCES}

Cowchok, S. F., Ferin, M., Dyrenfurth, I., Carmel, R., Zimmerman, E., Brinson, A. \& Vande WIELE, R. L. (1973) Active immunisation with oestradiol-17 $\beta$ bovine serum albumen in monkeys. In Gonadotrophins, pp. 87-97. Eds. B. B. Saxena, G. G. Belling and H. M. Gandy. WileyInterscience, New York.

Hillier, S. G., Cole, E. N., Groom, G. V., Boyns, A. R. \& Gameron, E. H. D. (1973) Effect of active immunisation against testosterone-3-BSA on circulating levels of testosterone, LH, prolactin and testosterone antibody titre in the male rat. Steroids, 22, 227-238.

Nieschlag, E., Usadel, K. H., Schwedes, U., Kley, H. K., Schöprling, K. \& KRüskemper, H. L. (1973) Alterations in testicular morphology and function in rabbits following active immunisation with testosterone. Endocrinology, 92, 1142-1147.

Robinson, T. J. (1959) The oestrous cycle of the ewe and doe. In Reproduction in Domestic Animals, vol. 1, pp. 291-333. Eds. H. H. Cole and P. T. Cupps. Academic Press, New York and London.

Scaramuzzi, R. J., Caldwell, B. V., Tillson, S. A. \& Thorneycroft, I. H. (1970) Neutralisation of exogenous oestradiol activity following active immunisation procedures. In Research on Steroids, vol. 4, pp. 187-196. Eds. M. Finkelstein, A. Klopper, C. Conti and C. Cassano. Pergamon Press, Oxford and New York.

Scaramuzzi, R. J., Corker, C. S., Young, G. \& Baird, D. T. (1974) Production of antisera to steroid hormones in sheep. In Steroid Immunoassay, Eds. E. H. D. Cameron, S. G. Hillier and K. Griffiths. Alpha Omega Alpha Publications, Caerphilly (in press).

Sundaram, K., Tsong, Y. Y., Hood, W. \& Brinson, A. (1973) Effect of immunisation with oestroneprotein conjugate in rhesus monkeys. Endocrinology, 93, 843-847.

Thorneycroft, I. H. (1973) The effects of active immunisation against testosterone on serum testosterone and ICSH in rabbits. Biol. Reprod. 8, 396.

Thorneycroft, I. H., Tillson, S. A., Abraham, G. E., Scaramuzzi, R. J. \& Caldwell, B. V. (1970) Preparation and purification of antibodies to steroids. In Immunologic Methods in Steroid Determination, pp. 63-85. Eds. F. G. Péron and B. V. Caldwell. Appleton-Century-Crofts, New York.

Vaitukaitis, J., Robbins, J. B., Nieschlag, E. \& Ross, G. T. (1971) A method for producing specific antisera with small doses of immunogen. F. clin. Endocr. Metab. 33, 988-991.

Vande Wiele, R. L., Ferin, M., Razlano, J., Dyrenfurth, I. \& Mikhail, G. (1970) Studies with antibodies to steroids. In Research on Steroids, vol. 4, pp. 171-185. Eds. M. Finkelstein, A. Klopper, C. Conti and C. Cassano. Pergamon Press, Oxford and New York. 